\title{
Processing Organic Waste Towards High Performance Carbon Electrodes for Electrochemical Capacitors
}

\author{
Krzysztof Wasiński ${ }^{1, *}$, Piotr Nowicki ${ }^{2}$, Paulina Pótrolniczak ${ }^{1}$, Mariusz Walkowiak ${ }^{1}$, Robert Pietrzak ${ }^{2}$ \\ ${ }^{1}$ Institute of Non-Ferrous Metals, Division in Poznań, Central Laboratory of Batteries and Cells, \\ Forteczna 12, 61-362 Poznań, Poland \\ ${ }^{2}$ Adam Mickiewicz University in Poznań, Faculty of Chemistry, Laboratory of Applied Chemistry, \\ Umultowska 89b, 61-614 Poznań, Poland \\ *E-mail: krzysztof.wasinski@claio.poznan.pl
}

doi: $10.20964 / 2017.01 .36$

Received: 28 September 2016 / Accepted: 11 November 2016 / Published: 12 December 2016

\begin{abstract}
Electrochemical properties of a family of carbons obtained from bio-waste have been investigated in terms of their application as electrode materials in electrochemical double layer capacitors. The precursor materials have been subjected to a special treatment involving activation in potassium carbonate and carbonization at $800^{\circ} \mathrm{C}$ in the flow of nitrogen. The resulting activated carbons exhibited high specific surface areas ranging from 840 to $1200 \mathrm{~m}^{2} \mathrm{~g}^{-1}$ and the total content of functional groups between 1.0 and $1.7 \mathrm{mmol}$ per gram, depending on the source fruit material. Symmetrical capacitors have been assembled with two kinds of electrolytes, namely $6 \mathrm{M} \mathrm{KOH}$ in water and $1 \mathrm{M}$ tetraethylammonium tetrafluoroborate in acetonitrile. Electrochemical characterization involved cyclic voltammetry, galvanostatic charge/discharge and electrochemical impedance spectroscopy techniques. Specific capacitances have been found to exceed $100 \mathrm{~F} \mathrm{~g}^{-1}$ for $0.1 \mathrm{~A} \mathrm{~g}^{-1}$ and to range from 17 to $45 \mathrm{~F} \mathrm{~g}^{-}$ ${ }^{1}$ for $10 \mathrm{~A} \mathrm{~g}^{-1}$ in the aqueous electrolyte. In the organic electrolyte specific capacitances of 70 to $100 \mathrm{~F}$ $\mathrm{g}^{-1}$ for $0.1 \mathrm{~A} \mathrm{~g} \mathrm{~g}^{-1}$ and 27 to $34 \mathrm{~F} \mathrm{~g}^{-1}$ for $10 \mathrm{~A} \mathrm{~g}^{-1}$ were determined. The observed high capacitances confirm that carbons obtained from waste biomass can be considered as promising electrode materials for high-performance supercapacitors.
\end{abstract}

Keywords: biowaste processing, one-step carbonization and activation, activated carbons, supercapacitors

\section{FULL TEXT}

(C) 2017 The Authors. Published by ESG (www.electrochemsci.org). This article is an open access article distributed under the terms and conditions of the Creative Commons Attribution license (http://creativecommons.org/licenses/by/4.0/). 